\title{
Biochemical Evaluation of the Effects of Hydromethanolic Extracts of Dioscorea bulbifera in Wistar Rats
}

\author{
$*{ }^{1}$ Chinko, BC, ${ }^{2}$ Dapper, DV,${ }^{3}$ Adienbo, OM,${ }^{4}$ Egwurugwu, JN, ${ }^{5}$ Uchefuna, RC \\ ${ }^{1-3}$ Department of Human Physiology, University of Port Harcourt, Port Harcourt. Rivers State. Nigeria \\ ${ }^{4}$ Department of Physiology, Imo State University, Owerri, Imo State Nigeria \\ ${ }^{5}$ Department of Physiology, NnamdiAzikiwe University, Awka, Anambra State Nigeria \\ *corresponding author: bruno.chinko@uniport.edu.ng
}

\begin{abstract}
The use of plants for medicinal purposes in Africa and other parts of the world have continued to be seen as safe alternatives to conventional medicine. Dioscorea bulbifera remains one of the widely used therapeutic plants in Africa and Asia. The present study is aimed at studying the biochemical effects of hydromethanolic extract of Dioscorea bulbifera on biochemical parameter using Wistar rats. Forty (40) albino Wistar rats were used for the study and were divided into 4 groups of 10 rats each. The control group received distilled water while the experimental groups received hydromethanolic extracts of Dioscorea bulbifera at $20 \mathrm{mg} / \mathrm{kg}, 50 \mathrm{mg} / \mathrm{kg}$ and $100 \mathrm{mg} / \mathrm{kg}$. Serum glucose, proteins, lipid profile and liver enzymes were analyzed using standard laboratory methods. Results of the present study indicate that the mean values for serum glucose, albumin, TG, TC, LDL, VLDL and atherogenic index was found to be statistically higher in experimental group compared to control $(p<0.05)$ while the mean values for to total protein, ALT and AST was found to be significantly higher in experimental group compared to control $(p<0.05)$. These results show a potent hypoglycaemic and hypolipidaemic activity of the extract.
\end{abstract}

Key words; Dioscorea bulbifera, lipid profile,serum glucose, liver enzymes

\section{Introduction}

The use of plants for medicinal purposes in African predates the recent global use of a variety of herbal products and home remedies[1]. Traditional medicine evolved from environmental resources, which the people of a community adapted in desperation for survival from disease and remained the sole medical system for health care before the advent of modern medicine[2]. Today herbal products are often promoted as being "natural" and completely "safe" alternatives to conventional medicines, however many are potentially toxic[3]. The source of contamination may due to an inadvertent contamination by microbial or chemical agents during any of the production stages or by other species or plant parts through misidentification with resultant unsafe consequences. While herbal remedies have a wide range of therapeutic uses and are suitable for chronic treatments; the occurrence of undesirable side effects seems to be less frequent. However, well-controlled, randomized clinical trials have revealed that side effects also exist.[1, 3, 4]

Dioscorea bulbifera also known as aerial or air potato is one of the highly grown yam in West Africa and Asia. They are not only grown for food but also for its use in herbal preparations in many parts of the world[5, 6]. In Nigeria, herbal preparation using Dioscorea bulbifera is used for memory enhancement, antiaging, constipation and fever[7] while in Zimbabwe it used as an infusion to apply to cuts and sores[6]. In Cameroon and Madagascar, the pounded bulbils are applied to abscesses, boils and wound infections[8]. In traditional Indian and Chinese medicine, it used in the treatment of goiter, sore throat, gastric cancer and carcinoma of the rectum $[9,10]$.

Reports on the extracts of Dioscorea bulbifera have demonstrated its anti-fungal activity[11], antibacterial potential [12], protective capability in mycordial ischemic reperfusion injury[13], wound healing ability[14], analgesic and anti-inflammatory properties[5] and antioxidant and gastroprotective effects[15, 16]. Despite its widely acclaimed therapeutic potential, information regarding its effects on biochemical parameters is meagre. The present study therefore is an attempt to evaluate the effects of hydromethanolic extract of Dioscorea bulbifera on biochemical parameters using Wistar rat models.

\section{Materials And Methods}

\section{Research Animals}

Forty (40) albino Wistar rats weighing $180-300 \mathrm{~g}$ were used for the study. The rats were allowed three weeks of acclimatization under standard laboratory conditions (Temp. $25-29^{\circ} \mathrm{C}$, natural light/dark cycle) during which they were fed a balanced commercial rat pellet diet ad libitum. 


\section{Preparation of Plant Extract}

The aerial tubers of Dioscorea bulbifera were freshly harvested from a farm in Amiri, Imo State. They were thoroughly washed, sliced into fine small pieces, and shade dried for 2 weeks. They were then reduced to coarse powdery form by grinding followed by soxhlethydromethanolic extraction as described by Odebiyi and Sofowora[17].

\section{Experimental Design}

The rats where divided into 4 groups (Groups1, 2, 3 and 4) of 10 rats per group.

Group 1 (control) received distilled water

Group 2 received 20mg/kg of Diosocorea bulbifera extract

Group 3 received $50 \mathrm{mg} / \mathrm{kg}$ of Diosocorea bulbifera extract

Group 4 received $100 \mathrm{mg} / \mathrm{kg}$ of Diosocorea bulbifera extract

The oral administration of the extracts lasted for 20 days.

\section{Collection of Blood Sample and Laboratory Analysis}

The animals were sacrificed using chloroform anesthesia followed by cardiac puncture. Blood was collected into a dry sample bottle for biochemical parameters using standard laboratory kits (Randox Laboratories Ltd., UK)

\section{Histopathological examination of the Liver}

The animals were dissected by the method described by Patel et al[18]. The liver was harvested and cut into sections. The sections were fixed directly on a slide and stained with haematoxylin and eosin, examined at $\mathrm{x} 400$ and photographed.

\section{Statistical Analysis}

The mean and standard error of mean were determined using SPSS v.20.The one way ANOVA followed by an LSD post hoc analysis was used to determine the difference among the groups. The results were considered significant at $\mathrm{p}$-value $<0.05$. Results are presented as mean \pm standard error of mean.

\section{Results}

The result of the phytochemical screening revealed the presence of carbohydrates, cholesterol, alkaloids, steroids/triterpenoids, tannins, saponins, flavonoids, anthraquinones, cardiac glycosides, phenols, proteins and amino acids.

Table 1: The effects of hydromethanolic extract of Dioscoreabulbibera on serum total protein, albumin, alkaline phosphatase, alanine transaminase and aspartate transaminase

\begin{tabular}{|c|c|c|c|c|}
\hline Parameters & $\begin{array}{c}\text { Group 1 } \\
\text { (Control) } \\
\mathbf{n}=10\end{array}$ & $\begin{array}{c}\text { Group } 2 \\
(20 \mathrm{mg} / \mathrm{kg} \mathrm{DB}) \\
\mathrm{n}=10\end{array}$ & $\begin{array}{c}\text { Group 3 } \\
(50 \mathrm{mg} / \mathrm{kg} \mathrm{DB}) \\
\mathrm{n}=10\end{array}$ & $\begin{array}{c}\text { Group } 4 \\
(100 \mathrm{mg} / \mathrm{kg} \text { DB }) \\
\mathrm{n}=10\end{array}$ \\
\hline Albumin (g/L) & $41.92 \pm 1.30$ & $37.50 * \pm 0.96$ & $44.25 \pm 0.75$ & $33.33 * \pm 0.71$ \\
\hline $\begin{array}{c}\text { Total Protein }(\mathrm{g} / \mathrm{L}) \\
\end{array}$ & $73.17 \pm 2.42$ & $93.75^{*} \pm 3.21$ & $85.17 * \pm 2.77$ & $82.58 \pm 1.51 *$ \\
\hline Alkaline Phosphatase (ALP) (U/L) & $42.83 \pm 3.93$ & $44 \pm 2.93$ & $49.00 \pm 1.32$ & $46.17 \pm 2.93$ \\
\hline Alanine Transaminase (ALT) (U/L) & $21.33 \pm 1.04$ & $16.75 \pm 0.96$ & $22 \pm 0.52$ & $36.25 * \pm 4.88$ \\
\hline Aspartate Transaminase (AST) (U/L) & $79.25 \pm 1.46$ & $76 \pm 0.01$ & $81.92 \pm 1.85$ & $81.92 * \pm 1.81$ \\
\hline
\end{tabular}

Table 2: The effects of hydromethanolic extract of Dioscorea bulbifera on serum glucose, lipid profile and atherogenic index

\begin{tabular}{|c|c|c|c|c|}
\hline Parameters & $\begin{array}{c}\text { Group 1 } \\
\text { (Control) } \\
\mathbf{n}=\mathbf{1 0}\end{array}$ & $\begin{array}{c}\text { Group } 2 \\
(20 \mathrm{mg} / \mathrm{kg} \text { DB }) \\
\text { n }=10\end{array}$ & $\begin{array}{c}\text { Group 3 } \\
(50 \mathrm{mg} / \mathrm{kg} \mathrm{DB}) \\
\mathbf{n}=10\end{array}$ & $\begin{array}{c}\text { Group } 4 \\
(100 \mathrm{mg} / \mathrm{kg} \text { DB }) \\
\mathrm{n}=10\end{array}$ \\
\hline Glucose $(\mathrm{mmol} / \mathrm{L})$ & $7.82 \pm 0.14$ & $6.86 \pm 0.28 *$ & $6.52 \pm 0.24$ & $6.28 \pm 0.32 *$ \\
\hline Total Cholesterol (TC) (mmol/L) & $3.82 \pm 0.05$ & $3.54 \pm 0.10 *$ & $3.34 \pm 0.08 *$ & $3.28 \pm 0.12 *$ \\
\hline Total triglycerides (TG) (mmol/L) & $0.80 \pm 0.04$ & $0.49 \pm 0.05 *$ & $0.45 \pm 0.05 *$ & $0.47 \pm 0.03^{*}$ \\
\hline High density Lipoproteins (HDL) (mmol/L) & $2.66 \pm 0.17$ & $3.01 \pm 0.15$ & $2.67 \pm 0.17$ & $2.86 \pm 0.12$ \\
\hline Low density Lipoproteins (LDL) (mmol/L) & $0.79 \pm 0.14$ & $0.31 \pm 0.12 *$ & $0.47 \pm 0.10 *$ & $0.21 \pm 0.05 *$ \\
\hline Very Low density Lipoproteins (VLDL) (mmol/L) & $0.37 \pm 0.02$ & $0.22 \pm 0.02 *$ & $0.21 \pm 0.02 *$ & $0.22 \pm 0.01 *$ \\
\hline $\begin{array}{ll}\text { Atherogenic Index } \\
\end{array}$ & $0.52 \pm 0.04$ & $-0.81 \pm 0.07 *$ & $-0.79 \pm 0.07 *$ & $-0.79 \pm 0.03 *$ \\
\hline
\end{tabular}

Table 3: The effects of hydromethanolic extract of Diosocreabulbiberaon body weight of wistar rats

\begin{tabular}{|c|c|c|c|c|}
\hline & $\begin{array}{c}\text { Body Weight (g) } \\
\text { Week 1 }\end{array}$ & $\begin{array}{c}\text { Body Weight (g) } \\
\text { Week 2 }\end{array}$ & $\begin{array}{c}\text { Body Weight (g) } \\
\text { Week 3 }\end{array}$ & $\begin{array}{c}\text { Body Weight (g) } \\
\text { Week 4 }\end{array}$ \\
\hline Group 1 (Control, n=10) & $275 \pm 8.21$ & $283.33 \pm 9.48$ & $280.67 \pm 7.72$ & $290 \pm 10.48$ \\
\hline Group 2 (20mg/kg, n=10) & $260 \pm 10.73$ & $258.33 \pm 10.86$ & $268.33 \pm 9.36$ & $255.83 \pm 8.48$ \\
\hline Group 3 (50mg/kg, n=10) & $276.67 \pm 8.82$ & $261.87 \pm 8.33$ & $254.2 \pm 8.53 *$ & $230.67 \pm 7.42 *$ \\
\hline
\end{tabular}


Biochemical Evaluation of the Effects of Hydromethanolic Extracts of Dioscorea bulbifera in ....

\begin{tabular}{|l|l|l|l|l} 
Group 4 (100mg/kg, n=10) & $298.33 \pm 5.75$ & $290.33 \pm 9.36$ & $293 \pm 8.88$ & $250.33 \pm 7.96^{*}$
\end{tabular}

Fig 1: The effects of hydromethanolic extract of Diosocreabulbibera on liver histology of wistar rats

1A

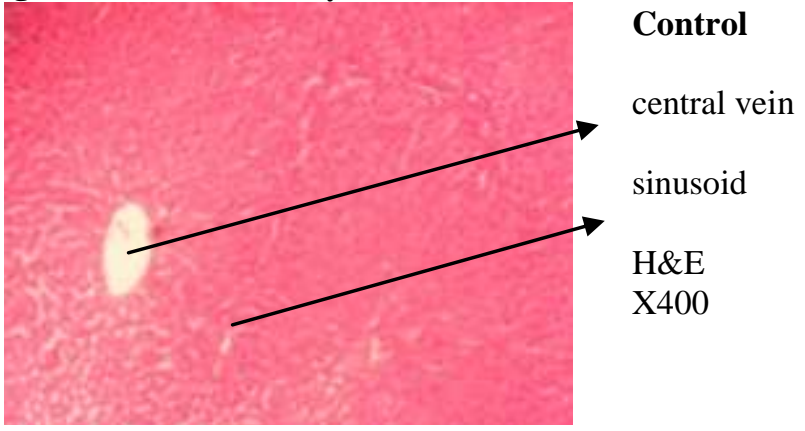

$1 B$

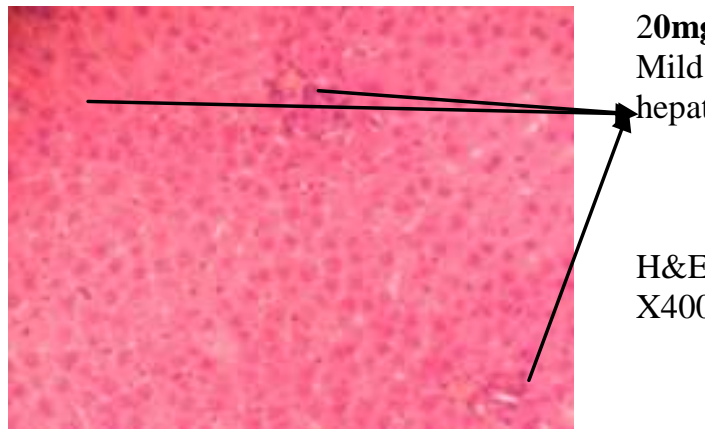

Mild inflammatory cells accumulation around the hepatocytes

$1 \mathrm{C}$

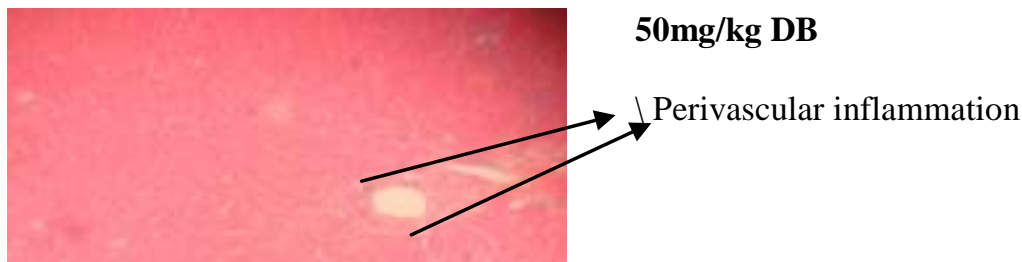

$\mathrm{H} \& \mathrm{E}$

$\mathrm{X} 400$

1D

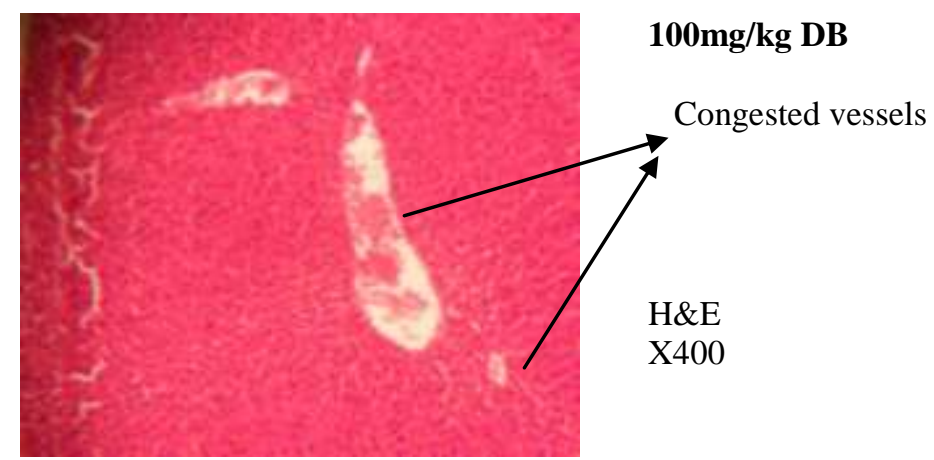

Table 1 shows the effect of hydromethanolic extract of Dioscorea bulbifera on serum total protein, albumin, alkaline phosphatase, alanine transaminase (ALT) and aspartate transaminase (AST). Mean values of serum total protein, album, ALT and AST were found to be significantly higher in experimental group compared to control $(\mathrm{p}<0.05)$.

Table 2 shows the effects of the extract on serum glucose, TC, TG, HDL, LDL, VLDL and atherogenic index. Mean values of serum glucose, TC, TG, LDL and VLDL were found to be statistically lower in experimental group compared to control $(\mathrm{p}<0.05)$ while mean values for HDL did not show any trend. 
Table 3 shows the mean body weights of Wistar rats following the 28days administration of hydroomethanolic extract of Dioscorea bulbifera. While significantly higher mean body weights were obtained for control rats compared to the experimental group in the fourth week $(\mathrm{p}<0.05)$, significantly lower mean body weights were obtained for experimental rats in groups 3 and 4 in the third and fourth weeks of the administration of the extract compared to control. There was a general decrease in body weight of the rats in the experimental group compared to control. The atherogenic index was found to be lower in the experimental group compared to control $(\mathrm{p}<0.05)$.

Figure 1 shows the micrographs of liver histology of the animals in the various groups with $1 \mathrm{~A}, 1 \mathrm{~B}, 1 \mathrm{C}$ and $\mathrm{D}$ representing liver histology for groups 1,2, 3 and 4 respectively. Normal liver histology is shown in Fig.1A while Figs. 1B, 1C and D show various forms of liver damages.

\section{Discussion}

Biochemical markers continues to provide information regarding the state of physiological well-being following, illness, malnutrition and the effects of exogenous compounds taken into the body[19, 20]. The present study evaluated the effects of hydromethanolic extract of Dioscorea bulbifera on lipid profile, serum glucose, proteins and liver enzymes of wistar rats.

Mean values serum glucose was found to be statistically lower in experimental groups $(6.86 \pm 0.28$, $6.52 \pm 0.24$ and 6.28 \pm 0.32 ) compared to control group $(7.82 \pm 0.14)$ in a dose dependent manner. This is attributable to the effect of Dioscorea bulbifera which has been shown to be a potent potentglucosidase and $\alpha$ amylase inhibitor[21] which lowers the rate of glucose absorption through delayed carbohydrate digestion . It may also be due to the an extra pancreatic mechanism of inhibition of hepatic glucose production[22, 23]. It is also possible that the extract stimulated insulin secretion from the $\beta$-cells of the islets of Langerhans [23, 24]. Dioscorea bulbifera has also be shown to have a potent hypoglycaemicactivity [21, 24-26].

The mean values for TC, TG, LDL and VLD were all found to be significantly lower in the experimental group compared to control $(\mathrm{p}<0.05)$ as shown in Table 2 . The effect of Dioscorea bulbifera to caused reduced serum cholesterol levels could be due their anti-oxidant activity[15, 16] as they prevent the oxidative modification of LDL. Also triterpenoids as found to be a phytochemical component of the extract has been demonstrated to reduce the levels of TG, TG and phospholips.[27]. In the same way, saponins have been associated with a decreased intestinal absorption of cholesterol[28] by binding cholesterol to the lumen, reducing its absorption, increasing its fecal excretion and consequently lowering blood cholesterol[29]. Saponins have also been reported to exhibit anti-lipase activity, reduced adipocyte differentiation and lipogenesis[30, 31].

The observed hypolipidaemic activity of Dioscorea bulbifera extract consequently improved the atherogenic index in the experimental group compared to control. The mean value of atherogenic index was found to be statistically lower in the experimental groups $(-0.81 \pm 0.07,0.79 \pm 0.07,0.79 \pm 0.03)$ compared to control $(0.81 \pm 0.07)(\mathrm{p}<0.05)$

The liver is involved in the metabolic transformation of drugs and other chemicals and hence it is normally predisposed to damages. [32]. Serum levels of liver enzymes, ALT, AST and ALP have been shown to be reliable markers of hepatotoxicity[33]. While the mean values for total protein, ALT and AST was found to be significantly increased in the experimental groups compared to control $(\mathrm{p}<0.05)$, the mean values for serum albumin was significantly decreased in the experimental group compared to control $(\mathrm{p}<0.05)$. This observed increase in the activities of ALT and AST in the experimental animalsmay have resulted from leakages from damaged hepatocytes[34]. The observed hepatocellular injury as shown in the micrograph (Fig.1) of liver histology of the experimental animals suggests a chemically-induced liver damage. The various forms of hepatocellular injury observed include the presence of inflammatory cells around the hepatocytes, perivascular inflammation and congested vessels.

The significant decrease in serum albumin levels $(37.50 \pm 0.96,38.25 \pm 0.75$ and $33.33 \pm 0.71)$ observed in the experimental groups compared to the control group $(41.92 \pm 1.36)$ could be due to liver damage which prevented the liver from producing albumin[35]. The mean value for total protein was also found to be statistically higher in experimental group compared to control $(83.75 \pm 3.21,83.17 \pm 2.77$ and 82.58 \pm 0.71$)$. This could be attributed to the inflammatory changes as observed in the micrograph of liver histology (Fig 1B, 1C and 1D) [36].

While the body weights of control animals expectedly increased, the body weight of the experimental groups were observed to decrease following the administration of hydromethanolic extract Dioscorea bulbifera. This could be attributed to ability of the extract to reduce serum TG, TC and LDL. Also saponins have been found to cause appetite suppression mediated via regulation of hypothalamic neuropeptide Y and serum leptin levels[37, 38].

\section{Conclusion}


The result of present study indicate that the oral administration of hydromethanolic extract of Dioscorea bulbifera reduced serum glucose, lipid profile and consequently the weight of the animals. However, the sub-chronic administration of this extract caused visible liver toxicity. While these findings suggest a potent hypoglycaemic and hypolipidaemic activity, we recommend further research on the acute, sub-acute and chronic administration of this extract on liver function.

\section{References}

[1]. Adewunmi CO, Ojewole JAO: Editorial-Safety of traditional medicines, complementary and alternative medicines in Africa. African journal of traditional, complementary and alternative medicines 2004, 1(1):1-3.

[2]. Okoli R, Aigbe O, Ohaju-Obodo J, Mensah J: Medicinal herbs used for managing some common ailments among Esan people of Edo State, Nigeria. Pakistan Journal of Nutrition 2007, 6(5):490-496.

[3]. Fennell C, Lindsey K, McGaw L, Sparg S, Stafford G, Elgorashi E, Grace O, Van Staden J: Assessing African medicinal plants for efficacy and safety: pharmacological screening and toxicology. Journal of Ethnopharmacology 2004, 94(2):205-217.

[4]. Calixto J: Efficacy, safety, quality control, marketing and regulatory guidelines for herbal medicines (phytotherapeutic agents). Brazilian Journal of Medical and Biological Research 2000, 33(2):179-189.

[5]. Mbiantcha M, Kamanyi A, Teponno R, Tapondjou A, Watcho P, Nguelefack T: Analgesic and anti-inflammatory properties of extracts from the bulbils of Dioscorea bulbifera L. var sativa (Dioscoreaceae) in mice and rats. Evidence-Based Complementary and Alternative Medicine 2010, 2011.

[6]. Subhash C, Sarla S, Abhay MP, Anoop B: Nutritional profile and phytochemical screening of Garhwal Himalaya medicinal plant Dioscorea bulbifera. Int Res J Pharm 2012, 3(5):289-294.

[7]. Odugbemi T: A textbook of medicinal plants from Nigeria: Tolu Odugbemi; 2008.

[8]. Cogne A: Phytochemical investigation of plants used in African medicine: Dioscorea sylvatica (Dioscoreaceae), Urginea altissima (Liliaceae), Jamesbrittenia fodina and Jamesbrittenia elegantissima (Scrophulariaceae). Doctorat Theses University of Lausanne, Lausanne 2002.

[9]. Gao H, Wu L, Kuroyanagi M: Seven Compounds from Dioscorea bulbifera L.(Natural Medicine Note). Natural Medicines 2001, 55(5):277.

[10]. Jiang S: Dictionary of Chinese Crude Drugs. Shanghai Scientific and Technical Publishers, Shanghai, China, New Medical College edition 1978.

[11]. Adeleye A, Ikotun T: Antifungal activity of dihydrodioscorine extracted from a wild variety of Dioscorea bulbifera L. Journal of basic microbiology 1989, 29(5):265-267.

[12]. Adeosun OM, Arotupin DJ, Toba OA, Adewole A: Antibacterial activities and phytochemical properties of extracts of Dioscorea bulbifera Linn (Air Potatoe) tubers and peels against some pathogenic bacteria. 2016.

[13]. R Vasanthi H, ShriShriMal N, K Das D: Phytochemicals from plants to combat cardiovascular disease. Current medicinal chemistry 2012, 19(14):2242-2251.

[14]. Panduraju T, Bitra V, Vemula S, Reddy P: Wound healing activity of Dioscorea bulbifera Linn. Journal of Pharmacy Research 2010, 3(12):3138-3139.

[15]. Suriyavathana M, Indupriya S: Screening of antioxidant potentials in Dioscorea bulbifera. Int J Pharm Life Sci 2011, 2(4):661-664.

[16]. Balasubramanian J, Dhanalakshmi R, Jibnomen P, Manimekalai P: A preclinical evaluation on antioxidant and gastroprotective effect of Dioscorea bulbifera in Wistar rats. Indian Journal of Innovations and Developments 2012, 1(3):149-154.

[17]. Odebiyi O, Sofowora E: Phytochemical screening of Nigerian medicinal plants II. Lloydia 1977, 41(3):234-246.

[18]. Patel P, Sweiss K, Shatavi S, Peace D, Clark N, Rondelli D: The impact of novel influenza A (H1N1) after hematopoietic SCT. Bone marrow transplantation 2010, 45(12):1756-1757.

[19]. Basu I, Subramanian P, Prime M, Jowett C, Levack B: The use of biochemical parameters as nutritional screening tools in surgical patients. Surgical Science 2011, 2(2):89.

[20]. Patterson BM, Cornell C, Carbone B, Levine B, Chapman D: Protein depletion and metabolic stress in elderly patients who have a fracture of the hip. J Bone Joint Surg Am 1992, 74(2):251-260.

[21]. Ghosh S, Ahire M, Patil S, Jabgunde A, Bhat Dusane M, Joshi BN, Pardesi K, Jachak S, Dhavale DD, Chopade BA: Antidiabetic activity of Gnidia glauca and Dioscorea bulbifera: potent amylase and glucosidase inhibitors. Evidence-Based Complementary and Alternative Medicine 2011, 2012.

[22]. Swanston-Flatt S, Day C, Bailey C, Flatt P: Traditional plant treatments for diabetes. Studies in normal and streptozotocin diabetic mice. Diabetologia 1990, 33(8):462-464

[23]. Oyedemi S, Yakubu M, Afolayan A: Antidiabetic activities of aqueous leaves extract of Leonotis leonurus in streptozotocin induced diabetic rats. Journal of Medicinal Plants Research 2011, 5(1):119-125.

[24]. Sharma SB, Nasir A, Prabhu KM, Murthy PS: Antihyperglycemic effect of the fruit-pulp of Eugenia jambolana in experimental diabetes mellitus. Journal of ethnopharmacology 2006, 104(3):367-373.

[25]. Okon J, Ofeni A: Antidiabetic effect of Dioscorea bulbifera on alloxan induced diabetic rats. CIBTech J Pharm Sci 2013, 2(1):1415.

[26]. Ghosh S, More P, Derle A, Patil AB, Markad P, Asok A, Kumbhar N, Shaikh ML, Ramanamurthy B, Shinde VS: Diosgenin from Dioscorea bulbifera: novel hit for treatment of type II diabetes mellitus with inhibitory activity against $\alpha$-amylase and $\alpha$-glucosidase. PloS one 2014, 9(9):e106039.

[27]. Sudhahar V, Kumar SA, Sudharsan PT, Varalakshmi P: Protective effect of lupeol and its ester on cardiac abnormalities in experimental hypercholesterolemia. Vascular pharmacology 2007, 46(6):412-418.

[28]. Elekofehinti OO, Omotuyi IO, Kamdem JP, Ejelonu OC, Alves GV, Adanlawo IG, Rocha JBT: Saponin as regulator of biofuel: implication for ethnobotanical management of diabetes. Journal of physiology and biochemistry 2014, 70(2):555-567.

[29]. Sidhu G, Oakenfull D: A mechanism for the hypocholesterolaemic activity of saponins. British Journal of Nutrition 1986, 55(03):643-649.

[30]. Chantre P, Lairon D: Recent findings of green tea extract AR25 (Exolise) and its activity for the treatment of obesity. Phytomedicine 2002, 9(1):3-8.

[31]. Wolfram S, Raederstorff D, Preller M, Wang Y, Teixeira SR, Riegger C, Weber P: Epigallocatechin gallate supplementation alleviates diabetes in rodents. The Journal of nutrition 2006, 136(10):2512-2518.

[32]. Olayinka ET, Ore A, Adeyemo OA, Ola OS, Olotu OO, Echebiri RC: Quercetin, a Flavonoid Antioxidant, Ameliorated Procarbazine-Induced Oxidative Damage to Murine Tissues. Antioxidants 2015, 4(2):304-321. 
[33]. Boone L, Meyer D, Cusick P, Ennulat D, Bolliger AP, Everds N, Meador V, Elliott G, Honor D, Bounous D: Selection and interpretation of clinical pathology indicators of hepatic injury in preclinical studies. Veterinary Clinical Pathology 2005, 34(3):182188 .

[34]. Amacher DE: Serum transaminase elevations as indicators of hepatic injury following the administration of drugs. Regulatory Toxicology and Pharmacology 1998, 27(2):119-130.

[35]. Thapa B, Walia A: Liver function tests and their interpretation. The Indian Journal of Pediatrics 2007, 74(7):663-671.

[36]. Schafer AI, Goldman L: Goldman-Cecil Medicine: Elsevier Health Sciences; 2016.

[37]. Kim HY, Kang MH: Screening of Korean medicinal plants for lipase inhibitory activity. Phytotherapy Research 2005, 19(4):359361 .

[38]. Weigle DS, Cummings DE, Newby PD, Breen PA, Frayo RS, Matthys CC, Callahan HS, Purnell JQ: Roles of leptin and ghrelin in the loss of body weight caused by a low fat, high carbohydrate diet. The Journal of Clinical Endocrinology \& Metabolism 2003 , 88(4):1577-1586. 